Jurnal Sain Veteriner, Vol. 37. No. 1. Juni 2019, Hal. 41-48

DOI : $10.22146 /$ jsv.44965

ISSN 0126-0421 (Print), ISSN 2407-3733 (Online)

Tersedia online di https://jurnal.ugm.ac.id/jsv

\title{
Karakterisasi dan Identifikasi Bakteri Enterobacteriaceae pada Telur Penyu Lekang (Lepidochelys olivacea) asal Lhok Pante Tibang, Banda Aceh
}

\section{Characterization and Identification of Enterobacteriaceae Bacteria in Turtle (Lepidochelys olivacea) Eggs Shells from Lhok Pante Tibang, Banda Aceh}

\author{
Risa Nursanty ${ }^{1 *}$, Widya Sari ${ }^{1}$, Safranita $^{2}$ \\ ${ }^{1}$ Jurusan Biologi, Fakultas Matematika dan Ilmu Pengetahuan Alam, Universitas Syiah Kuala \\ ${ }^{2}$ Program Sarjana Biologi, Fakultas Matematika dan Ilmu Pengetahuan, \\ Universitas Syiah Kuala \\ *Email: risa_nursanty@unsyiah.ac.id
}

Naskah diterima : 11 April 2019, direvisi : 3 Mei 2019, disetujui : 30 Mei 2019

\begin{abstract}
The population of olive ridley turtle (Lepidochelys olivacea) are currently thretened with extinction, among the contributing factors is the failure of turtle eggs to hatch. The condition can be caused by the presence of bacterial contamination, especially group Enterobacteriaceae. The purpose of this research was to isolate the group of Enterobacteriaceae bacteria from olive ridley turtle. The sample used were shells from olive ridley turtle eggs comes from natural captivity in Lhok Pante Tibang Beach, Banda Aceh. The research parameters included the number of isolates, macroscopic morphology (shape, edge, elevation, and color of isolates), cell morphology (Gram staining and cell shape), and biochemical tests. Isolation method using spread plate and quadrant method. The isolation results obtained five isolates which had varying macroscopic morphology. The five isolates were Gram negative and formed such as trunk. Identification results found that there were three genus from Enterobacteriaceae videlicet two isolates were Enterobacter, two isolates as Shigella and the other were Klebsiella.
\end{abstract}

Keywords: Isolate, Enterobacteriaceae; Lepidochelys olivacea shells; Lhok Pante Tibang

\begin{abstract}
Abstrak
Populasi penyu lekang (Lepidochelys olivacea) saat ini terancam punah, diantara faktor penyebabnya adalah kegagalan telur penyu untuk menetas. Kondisi tersebut dapat diakibatkan oleh adanya kontaminasi bakteri, khususnya oleh kelompok Enterobacteriacea. Tujuan penelitian ini untuk mengisolasi kelompok bakteri Enterobacteriaceae pada telur penyu lekang. Sampel yang digunakan adalah cangkang dari telur penyu lekang yang berasal dari penangkaran alami di Pantai Lhok Pante Tibang, Banda Aceh. Parameter penelitian meliputi jumlah isolat, morfologi makroskopis (bentuk, tepian, elevasi, dan warna isolat), morfologi sel (pewarnaan Gram dan bentuk sel), serta uji biokimia. Metode isolasi menggunakan metode cawan sebar dan metode kuadran. Hasil isolasi mendapatkan lima isolat bakteri yang memiliki morfologi makroskopik yang bervariasi. Kelima isolat merupakan Gram negatif yang memiliki bentuk batang. Hasil identifikasi mendapatkan tiga genus dari Enterobacteriacea yaitu dua isolat genus Enterobacter, dua isolat sebagai Shigella dan lainnya genus Klebsiella.
\end{abstract}

Kata kunci: Isolasi, Enterobacteriaceae; Telur Lepidochelys olivacea; Lhok Pante Tibang

\section{Pendahuluan}

Penyu lekang (Lepidochelys olivacea) salah satu hewan yang terdaftar dalam 'red list' di The International Union for Conservation of Nature and Natural Resource (IUCN) dan Appendix I Convention on International Trade in Endangered Species (CITES) sehingga keberadaannya di alam memerlukan perhatian serius karena telah terancam punah (IUCN, 2018; CITES, 2018). Penyu bersifat karnivora dengan berat badan mencapai $40 \mathrm{~kg}$. Tubuh 
penyu dilingkupi oleh karapak yang keras. Karapak penyu lekang memiliki bentuk memanjang dan berwarna hijau gelap, dilengkapi dengan 5 pasang lempeng coastal yang setiap sisi terdiri dari 6-9 bagian. Bagian bawah karapak berwarna kuning. Kegiatan bertelur dilakukan pada malam hari, setiap sarang penyu lekang memiliki telur yang berjumlah 50-147. Telur penyu lekang secara alami umumnya membutuhkan masa inkubasi selama 48-52 hari (Dermawan dkk, 2009).

Lhok Pante Tibang yang terletak di Desa Deah Raya Kecamatan Syiah Kuala, Banda Aceh (5³5'44.37'U 95¹9'56.39”'T) merupakan salah satu pantai peneluran penyu di Aceh. Penyu lekang merupakan salah satu spesies penyu yang umum dijumpai dan juga bertelur di Lhok Pante Tibang (Sari dan Rahmad, 2014). Persyaratan untuk lokasi peneluran penyu diantaranya adalah pantai yang memiliki pasir halus, mudah dijangkau dari laut dan posisinya cukup tinggi untuk mencegah telur terendam oleh air pasang (Satriadi et al., 2003).

Salah satu faktor yang menyebabkan keberadaan penyu lekang terancam punah adalah gagal menetasnya telur penyu. Hal tersebut dapat disebabkan oleh kegiatan pemburuan telur oleh manusia maupun predator lain, pengaruh lingkungan dan kontaminasi bakteri (Phillott and Parmenter, 2001). Penelitian yang telah dilakukan oleh Sari dan Rahmad (2014), menemukan adanya kegiatan ilegal perburuan telur penyu di pantai Lhok Pante Tibang untuk dikonsumsi maupun diperjualbelikan. Saat ini belum terdapat informasi mengenai ada tidaknya kontaminasi mikroba khususnya bakteri pada telur penyu lekang yang ada di Lhok Pante Tibang.

Telur penyu selama masa inkubasi di dalam pasir (sarang) akan menyerap air, kondisi tersebut menyebabkan diameter atau volume telur menjadi lebih besar (Syaiful et al., 2013). Kadar air yang tinggi pada pasir sarang dapat mengakibatkan masuknya bakteri ke dalam cangkang pori-pori telur sehingga mengkontaminasi telur dan menghambat pertukaran gas (Rudiana et al., 2004). Umumnya bakteri yang mengkontaminasi telur penyu adalah kelompok Enterobacteriaceae diantaranya Shigella sp., Escherichia coli, Salmonella sp., Enterobacter, Proteus, Klebsiella sp. dan Aeromonas sp. (Hidayat et al., 2014; Morais et al., 2010). Penelitian Hidayat et al. (2014), berhasil mengisolasi bakteri Shigella sp., Salmonella sp. dan Klebsiella sp. dari cangkang telur penyu yang gagal menetas di penangkaran penyu Kota Pariaman. Berdasarkan informasi di atas maka perlu untuk mengetahui kemungkinan adanya kontaminasi bakteri khususnya kelompok Enterobacteriaceae yang berasal dari cangkang telur penyu lekang (Lepidochelys olivacea) yang diperoleh di Lhok Pante Tibang, Banda Aceh.

\section{Materi dan Metode}

\section{Waktu dan Lokasi Penelitian}

Penelitian ini berlangsung dari bulan Maret sampai dengan Juli 2016. Sampel telur penyu diperoleh dari Lhok Pante Tibang, Desa Deah Raya Kecamatan Syiah Kuala, Banda Aceh. Isolasi bakteri dilakukan di Laboratorium Mikrobiologi Jurusan Biologi Fakultas Matematika dan Ilmu Pengetahuan Alam (FMIPA) Universitas Syiah Kuala.

\section{Alat dan Bahan}

Alat yang akan digunakan pada penelitian ini adalah cawan petri (CMSI), botol sampel, jarum inokulasi, inkubator (Memmert), autoklaf (Yamato), erlenmeyer (Pyrex), bunsen, timbangan digital (Sartorius), mikroskop (Olympus), mortal, pastel, tabung ukur (Griffin), gelas ukur (Pyrex), tabung reaksi (Pyrex), pipet tetes, spatula, kamera (Samsung), alat tulis, gunting, pinset, kaca objek, dan kaca penutup. 
Bahan yang akan digunakan dalam penelitian ini adalah media Nutrient Agar (NA) Mac Conkey Agar, media Triple Sugar Iron Agar (TSIA), media Sulfid Indol Motility (SIM), media Methyl Red-Voges Proskauer (MR-VP) broth, media Simmone Citrate (SC), urea broth, reagen kovac, reagen methyl red, $\mathrm{KOH} 40 \%$, alfanaftol, kristal violet, larutan iodin, minyak emersi, safranin, dan alkohol 95\%, aluminium foil, plastik wrap, kertas label, sarung tangan (Protos), dan masker(Life Resources).

\section{Pengambilan dan persiapan sampel}

Cangkang telur penyu lekang yang berasal dari penangkaran terlebih dahulu dibersihkan dari kotoran dan juga pasir. Sampel cangkang telur penyu baik yang menetas ataupun yang gagal menetas, kemudian dimasukkan ke dalam botol sampel steril secara terpisah. Bagian cangkang dipisahkan dari isi telur dan kemudian direndam dalam gelas ukur yang berisi akuades steril selama 30 menit. Cangkang telur selanjutnya digerus dengan menggunakan mortar dan pastel.

\section{Isolasi bakteri}

Isolasi bakteri dilakukan dengan mengacu pada Sunatmo (2009). Cangkang telur yang telah halus dimasukkan dalam akuades steril hingga diperoleh pengencaran $10^{-1}$ dan dilakukan serial pengenceran hingga $10^{-7}$. Isolasi bakteri dilakukan dengan cara mengambil larutan sampel yang berasal dari tabung pengenceran $10^{-2}$. Sampel tersebut selanjutnya ditumbuhkan pada media padat Mac Conkey Agar menggunakan teknik cawan sebar yang diinkubasi pada suhu $37^{\circ} \mathrm{C}$ selama 24 jam. Setelah didapatkan beberapa jenis koloni berbeda, kemudian dilanjutkan dengan pemurnian isolat menggunakan teknik cawan gores. Cawan-cawan sampel tersebut kemudian diinkubasi dengan posisi terbalik pada suhu $37^{\circ} \mathrm{C}$ selama 24 jam.

\section{Karakterisasi dan Identifikasi bakteri}

Isolat bakteri yang diperoleh selanjutnya dikarakterisasi ciri makroskopis, pewarnaan Gram dan uji biokimia. Pencirian makroskopis yang diamati meliputi bentuk, tepian, elevasi, dan warna koloni bakteri. Adapun uji biokimia yang dilakukan hanya uji motilitas, indol, Methyl Red (MR), Voges-Proskauer (VP), Simmon Citrate (SC), Triple Sugar Iron Agar (TSIA), dan urease karena khusus untuk mengidentifikasi kelompok bakteri Enterobacteriacea (Sunatmo, 2009 dan Prescott et al. 2002). Interpretasi hasil identifikasi genus didasarkan hasil pewarnaan Gram dan uji biokimia bakteri yang selanjutnya mengacu pada buku Cowan and Steel's manual For Identification of Medical Bacteria (Borrow and Filtham, 2003)

\section{Hasil dan Pembahasan}

Lima isolat berhasil diperoleh dari sampel cangkang telur penyu lekang (Lepidopchelys olivaceae). Isolat-isolat bakteri tersebut memiliki ciri makroskopis berupa, bentuk bundar, tepian yang berombak (75\%) dan licin (25\%), serta elevasi cembung. Tiga isolat bakteri memiliki koloni berwarna merah muda dan lainnya berwarna merah. Sunatmo (2009), menyatakan pengamatan untuk ciri makroskopis yang meliputi bentuk, tepian, elevasi dan warna dilakukan secara visual. Pollack et al., (2005), menjelaskan bahwa pencirian makroskopis berguna untuk membedakan sifat-sifat pertumbuhan isolat bakteri pada berbagai media pertumbuhan. Morfologi makroskopis dan sel yang dimiliki isolat-isolat bakteri asal cangkang telur penyu lekang ditunjukkan pada Tabel 1 . 
Risa Nursanti, et. al.

Tabel 1. Karakterisasi morfologi makroskopis dan sel isolat asal cangkang telur penyu lekang

\begin{tabular}{|c|c|c|c|c|c|c|c|}
\hline \multirow[t]{2}{*}{ No } & \multirow{2}{*}{$\begin{array}{l}\text { Isolat asal } \\
\text { cangkang } \\
\text { telur penyu } \\
\text { lekang }\end{array}$} & \multicolumn{4}{|c|}{ Morfologi makroskopis } & \multicolumn{2}{|c|}{ Morfologi Sel } \\
\hline & & Bentuk & Warna & Tepian & Elevasi & $\begin{array}{c}\text { Pewarnaan } \\
\text { Gram }\end{array}$ & $\begin{array}{c}\text { Bentuk } \\
\text { Sel }\end{array}$ \\
\hline 1 & Isolat I & bundar & $\begin{array}{c}\text { merah } \\
\text { muda }\end{array}$ & berombak & cembung & negatif & batang \\
\hline 2 & Isolat II & bundar & $\begin{array}{l}\text { merah } \\
\text { muda }\end{array}$ & berombak & cembung & negatif & batang \\
\hline 3 & Isolat III & bundar & merah & berombak & cembung & negatif & batang \\
\hline 4 & Isolat IV & bundar & $\begin{array}{l}\text { merah } \\
\text { muda }\end{array}$ & berombak & cembung & negatif & batang \\
\hline 5 & Isolat $\mathrm{V}$ & bundar & merah & Licin & cembung & negatif & batang \\
\hline
\end{tabular}

Karakterisasi isolat bakteri yang meliputi pencirian makroskopis maupun sel dan uji biokimia dilakukan untuk mengidentifikasi genus ataupun spesies. Hal ini dikuatkan oleh Sunatmo (2009), bahwa identifikasi dilakukan untuk mencirikan suatu bakteri berdasarkan morfologi koloni, morfologi sel dan sifat-sifat fisiologi (biokimia). Berdasarkan data karakterisasi morfologi pada Tabel 1, kelima isolat diduga merupakan bakteri kelompok Gram negatif, khususnya kelompok Enterobacteriaceae. Prescott et al. (2002), menyatakan bahwa media Mac Conkey Agar merupakan media khusus untuk menumbuhkan kelompok bakteri Gram negatif berbentuk batang, baik yang dapat maupun yang tidak dapat memfermentasikan laktosa. Koloni bakteri yang memfermentasikan laktosa akan berwarna merah muda karena adanya neutral red (indikator $\mathrm{pH}$ ) yang akan berwarna merah jika pH di bawah 6,8. Koloni yang mampu memfermentasikan laktosa biasanya dikelilingi oleh endapan garam empedu. Endapan ini disebabkan oleh penguraian laktosa menjadi asam yang akan bereaksi dengan garam empedu.

Pencirian morfologi sel pada penelitian ini dilakukan secara mikroskopik meliputi pewarnaan Gram yang sekaligus dapat melihat bentuk sel bakteri. Hasil dari pewarnaan Gram memperlihatkan kelima isolat memiliki warna merah yang menunjukkan semua isolat bersifat Gram negative dan memiliki sel yang berbentuk batang. Uji biokimia yang dilakukan pada penelitian ini hanya pengujian terhadap pencirian bakteri dari kelompok Enterobacteriaceae. Hasil uji biokimia bakteri yang diisolasi dari cangkang telur penyu lekang dapat dilihat pada Tabel 2 .

Identifikasi bakteri yang dilakukan mengacu pada buku Cowan and Steel's manual For Identification of Medical Bacteria. Berdasarkan hasil identifikasi menunjukkan bahwa kelima isolat tersebut terdiri dari 3 genus bakteri Enterobacteriaceae. Dua isolat (isolat I dan isolat II) adalah genus Enterobacter. Adapun isolat III adalah genus Shigella, dua isolat lainnya (isolat IV dan isolat V) adalah genus Klebsiella. Morais et al. (2010) dan Keene (2012) menyatakan umumnya bakteri yang mengkontaminasi telur penyu adalah kelompok Enterobacteriaceae seperti Shigella sp., Enterobacter sp., Klebsiella sp., Escherichia coli, Proteus sp. dan Salmonella sp. Ketiga genus yang ditemukan yaitu genus Shigella, Enterobacter dan Klebsiella termasuk kedalam kelompok bakteri Enterobacteriaceae yang mampu menghasilkan toksin dan sering mengkontaminasi telur. Genus bakteri yang terisolasi dari cangkang telur penyu lekang selengkapnya pada Tabel 3 . 
Tabel 2. Uji biokimia isolat-isolat bakteri asal cangkang telur penyu lekang

\begin{tabular}{|c|c|c|c|c|c|c|}
\hline \multirow[b]{2}{*}{ No } & \multirow[b]{2}{*}{ Jenis uji } & \multicolumn{5}{|c|}{ Kode isolat } \\
\hline & & Isolat I & Isolat II & Isolat III & Isolat IV & Isolat V \\
\hline 1 & Uji motilitas & + & + & - & - & - \\
\hline 2 & Uji indol & - & - & - & - & - \\
\hline 3 & Uji MR & - & - & - & - & - \\
\hline 4 & Uji VP & + & + & + & + & + \\
\hline 5 & Uji SC & + & + & - & + & + \\
\hline 6 & Uji TSIA & & & & & \\
\hline & -sukrosa & - & - & - & - & + \\
\hline & -laktosa & + & + & - & + & + \\
\hline & -glukosa & + & + & - & + & + \\
\hline & -gas & + & + & - & + & + \\
\hline & $-\mathrm{H}_{2} \mathrm{~S}$ & - & - & - & - & - \\
\hline 7 & Uji urease & - & - & - & - & - \\
\hline
\end{tabular}

Keterangan : $+=$ bereaksi

- $=$ tidak bereaksi

Tabel 3. Genus bakteri Enterobacteriaceae asal cangkang telur penyu lekang di Lhok Pante Tibang, Banda Aceh

\begin{tabular}{clccc}
\hline No & \multicolumn{1}{c}{$\begin{array}{c}\text { Genus Bakteri } \\
\text { Enterobacteriaceae }\end{array}$} & \multicolumn{2}{c}{$\begin{array}{c}\text { Sumber Cangkang Telur } \\
\text { Gagal Menetas }\end{array}$} & Menetas \\
\hline 1 & Enterobacter & $\sqrt{ }$ & - \\
2 & Shigella & $\sqrt{ }$ & - \\
3 & Klebsiella & $\sqrt{ }$ & $\sqrt{ }$ \\
\hline
\end{tabular}

Keterangan : $\sqrt{ }=$ ditemukan

- = tidak ditemukan

Data yang terdapat pada Tabel 3. memperlihatkan bahwa genus Enterobacter, Shigella dan Klebsiella terdapat pada cangkang telur penyu lekang yang gagal menetas. Selain itu, pada penelitian ini juga didapat genus Klebsiella yang berasal dari cangkang telur penyu lekang yang menetas. Hasil identifikasi isolat bakteri pada penelitian ini menunjukkan adanya bakteri Enterobacteriacea pada semua cangkang telur penyu lekang yang menetas dan gagal menetas.

Genus Enterobacter diperoleh dari hasil isolasi cangkang telur penyu yang gagal menetas. Hasil penelitian Keene (2012), menemukan adanya genus Enterobacter pada telur penyu lekang yang gagal berkembang yang berasal dari Taman Nasional di daerah Guanacoste, Costa Rica. Bakteri Enterobacter termasuk bakteri yang patogen terhadap reptil.
Menurut Borrow and Filtham (2003) dan bakteri Enterobacter merupakan kelompok bakteri Enterobakteriaceae yang bersifat Gram negatif, berbentuk batang dan mampu memfermentasikan laktosa dan glukosa. Prescott et al. (2002), menyatakan sifat lain dari genus ini bersifat motil dan menunjukkan hasil positif terhadap uji sitrat. Sunatmo (2009), menjelaskan koloni bakteri tersebut akan berwarna merah muda dan mukoid jika ditumbuhkan pada media Mac Conkey Agar.

Genus Shigella diperoleh dari hasil isolasi cangkang telur penyu lekang yang gagal menetas. Bakteri genus Shigella dikenal dengan sifatnya yang patogen sehingga mampu mengkontaminasi telur penyu dan menyebabkan kegagalan penetasan. Hal ini diperkuat oleh Brock et al. (2008), yang menyatakan ciri dari bakteri patogen yaitu tidak dapat 
Risa Nursanti, et. al.

memfermentasikan laktosa seperti genus Shigella. Terdapatnya genus Shigella pada cangkang terlur yang gagal menetas ini sama halnya dengan hasil penelitian Hidayat et al. (2014), yang menyatakan genus Shigella terbukti terisolasi pada cangkang telur penyu lekang yang gagal menetas di penangkaran penyu Kota Pariaman. Penelitian Morais et al. (2010), juga menemukan bahwa genus Shigella terdapat pada telur kura-kura Podocnemis expansa dan Podocnemis unifilis di empat pantai yang berbatasan dengan Sungai Javae, Brazil. Menurut Borrow and Filtham (2003) dan Prescott et al. (2002), genus Shigella bersifat Gram negatif, berbentuk batang, nonmotil, hasil negatif terhadap uji sitrat dan tidak mampu memfermentasikan glukosa. Brooks et al. (2008), menyatakan bahwa Shigella merupakan organisme anaerob fakultatif tetapi tumbuh paling baik dalam kondisi aerob.

Genus Klebsiella diperoleh dari hasil isolasi cangkang telur penyu yang menetas dan gagal menetas. Genus ini bersifat patogen oportunistik, sehingga dapat menjadi flora normal pada usus manusia dan juga menjadi patogen jika kondisi inang yang melemah. Terdapatnya genus Klebsiella pada cangkang terlur yang menetas dan gagal menetas ini dijumpai juga pada hasil penelitian Hidayat et al. (2014), yang memaparkan bakteri genus Klebsiella terbukti terdapat pada cangkang telur penyu lekang yang menetas dan gagal menetas di penangkaran penyu Kota Pariaman. Menurut Borrow and Filtham (2003) dan Prescott et al. (2002), bakteri genus Klebsiella termasuk Gram negatif, berbentuk batang, nonmotil, positif terhadap uji sitrat dan mampu memfermentasikan laktosa dan glukosa. Sunatmo (2009), menyatakan jika genus ini ditumbuhkan pada media Mac Conkey Agar maka koloninya akan berwarna merah muda dan mukoid.

Keberadaan bakteri baik pada telur penyu yang menetas maupun yang gagal menetas ini diduga oleh faktor kelembaban tanah berpasir di sarang semi alami. Hatta (2016), melaporkan kelembaban tanah berpasir di sarang semi alami Lhok Pante Tibang yaitu 19,28\%. Menurut Rofiah et al. (2012), kelembaban minimal yang diperlukan untuk peneluran sarang penyu lekang yaitu 4-6\%. Hidayat et al. (2014), Cox et al. (2000) dan Rudiana et al. (2004), menyatakan kelembaban pada pasir sarang dapat memicu pertumbuhan bakteri sehingga menyebabkan kontaminasi terhadap telurtelur penyu, hal serupa ini terjadi juga pada telur unggas. Cox et al. (2000), menambahkan bahwa faktor lain penyebab kontaminasi bakteri adalah tipe cangkang, telur penyu lekang memiliki tipe parchment-shelled yang mudah menyerap air. Menurut Carven et al. (2007), kontaminasi bakteri pada telur telah terjadi sejak melewati saluran kloaka.

Bakteri yang bersifat patogen oportunistik merupakan flora normal yang dapat hidup dalam tubuh manusia normal yaitu salah satunya pada usus manusia, sehingga dapat diasumsikan keberadaan bakteri ini diduga adanya kontaminasi oleh feses dari saluran pencernaan manusia dan hewan di sarang semi alami. Menurut Brooks et al. (2008) dan Jawetz et al. (2004), bakteri Enterobacteriaceae dapat ditemukan di tanah, air, udara serta di saluran pencernaan manusia dan hewan. Bakteri Shigella dan Enterobacter merupakan contoh bakteri yang di hidup di saluran pencernaan manusia. Ini sesuai pernyataan Brooks et al. (2008) dan Prescott et al. (2002), bahwa bakteri genus Enterobacter, Shigella dan Klebsiella juga merupakan kelompok bakteri koliform. Keberadaan bakteri koliform dapat menjadi indikator adanya kontaminasi feses hewan maupun manusia.

Pengaruh lingkungan yang tidak bersih di sekitar sarang semi alami dapat memberikan peluang bagi bakteri untuk tumbuh pada telur penyu. Sarang semi alami yang dibuat pada penelitian ini tidak 
dibersihkan terlebih dahulu sebelum digunakan, hal ini memberikan peluang bagi bakteri untuk tumbuh, sehingga perlu dilakukan prosedur penanganan yang sesuai untuk melakukan konservasi penyu yang dimulai dari tahap awal pemindahan telur. Menurut Adnyana dan Creausa (2009) dan Dermawan et al. (2009), relokasi atau pemindahan telur yang dilakukan dari penetasan alami ke penetasan semi alami harus dilakukan dengan hati-hati karena sedikit kesalahan dalam prosedur akan menyebabkan gagalnya penetasan. Cara-cara pemindahan telur penyu ke penetasan semi alami diantaranya melakukan pembersihan pantai atau lokasi penetasan baru dari sampah organik maupun anorganik. Selanjutnya melakukan pemantauan pengamanan penyu bertelur, memindahkan telur penyu sebelum 2 jam setelah induk penyu bertelur ke sarang semi alami, telur penyu dimasukkan ke wadah dan dipindahkan secara hatihati, pemindahan dengan ember lebih baik dibanding dengan karung atau tas dan telur sebaiknya dihindarkan dari goncangan yang kuat karena dapat merobek membran atau selaput embrio telur penyu, apabila hal ini terjadi maka dapat mempermudah bakteri masuk ke dalam telur.

\section{Kesimpulan}

Hasil penelitian ini memperoleh adanya bakteri Enterobacteriaceae pada sampel penyu lekang yang menetas dan yang gagal menetas. Ada lima isolat bakteri yang terdiri dari dua isolat genus Enterobacter, genus Shigella dan dua isolat lainnya genus Kleibsiella.

\section{Daftar Pustaka}

Adnyana, I. B. W., dan Creausa, H. (2009). Panduan Melakukan Pemantauan Populasi Penyu di Pantai Peneluran di Indonesia. WWF, Indonesia dan Universitas Udayana.
Borrow, G. I., and Filtham, R. K.A. (2003). Cowan and Steel's Manual For Identification of Medical Bacteria. Cambrige University Press, USA.

Brooks, G. F., Butel, J. S., and Morse, S. A. (2008). Medical Microbiology. Mc Graw Hill, New York.

Cox, N. A., Berray, M. C., and Cason, J. A. (2000). Salmonella penetration of egg shells and proliferation in broiler hatching eggs A Review. Poultry Science. 79: 1571-1574.

Craven, J. E., Awong-Taylor, J., Griffiths, L. Bass, C., and Muscarella, M. (2007). Identification of bacteria isolates from unhatched loggerhead (Caretta caretta) sea turtles eggs in Georgia. Marine Turtle Newsletter. 115:7-9.

Dermawan, A., Nuitja, N. S., Soedharma, D., Halim, M. H., Kusrini, M. D., Lubis, S. B., Alhanif, R., Khazali, M., Murdiah, M., Wahjuhardini, P. L., Setiabudiningsih dan Mashar, A. (2009). Pedoman Teknis Pengelolaan Konservasi Penyu. Direktorat Konservasi dan Taman Nasional Laut, Direktorat Jenderal Kelautan, Pesisir dan Pulau-Pulau Kecil, Departemen Kelautan dan Perikanan RI, Indonesia.

Hatta, M. (2016). Pengaruh Karakteristik Pantai dan Naungan Sarang Terhadap Penetasan Telur Penyu Lekang (Lepidochelys olivacea) di Pantai Syiah Kuala, Banda Aceh dan Leupung, Aceh Besar. Skripsi. Fakultas Kelautan dan Perikanan, Universitas Syiah Kuala.

Hidayat, O., Fuji, A. F., dan Nasril, N. (2014). Isolasi dan Karakterisasi Bakteri pada Pasir Sarang dan Cangkang Telur Penyu lekang (Lepidochelys olivaceae L.) yang Menetas dan Gagal Menetas. Jurnal Biologi Universitas Andalas. 3 (2): 154-161.

Jawetz, E., Melnick, J. L., and Adelberg, E. A. (2004). Mikrobiologi Kedokteran. Terjemahan dari Medical Micrbiology, $23^{\text {th }}$ ed oleh Mudihardi, E., Kuntaman, Wasito, E. B., Mertaniasih, N. M., Harsono, S., dan Alimsardjono, L. Buku Kedokteran EGC, Jakarta.

Keen, E. L. (2012). Microorganism from sand, cloacal fluid and eggs of Lepidochelys olivacea and standard testing of cloacal fluid antiicrobial properties. Thesis. Purdue University. USA. 
Risa Nursanti, et. al.

Morais, P. Benevides de., Oliveira, K. Wessel de., Malvasio, A., Ataide, A. Gomes de., and Pimenta, R. S. (2010). Enterobacteriaceae Associated With Eggs of Podocnemis expansa and Podocnemis unifilis (Testudines: Chelonia) In Nonpolluted Sites of National Park of Araguaia Plains, Brazil. Journal of Zoo and Wildlife Medicine. 41 (4): 656-66.

Phillott, A. D., and Parmenter, C. J. (2001). Influence of Diminished Respiratory Surface Area on Survival of Sea Turtle Embryos. Journal Xperimental Zoology. 289: 317-321.

Prescott, L. M., Harley, J. P., and Klein, D. A. (2002). Microbiology Fifth Edition. The McGraw-Hill Companies, New York.

Rofiah, A., Retno, H., dan Edy, W. (2012). Pengaruh Naungan Sarang Terhadap Persentase Penetasan Telur Penyu lekang (Lepidochelys olivacea) di Pantai Samas Bantul, Yogyakarta. Journal of Marine Research. 1(2): 103-108.

Rudiana, E., Dwi, H. I., dan Nirwani, S. (2004) .Tingkat Keberhasilan Penetasan dan Masa Inkubasi Telur Penyu Hijau (Chelonia mydas
L) pada Perbedaan Waktu Pemindahan. Jurnal Ilmu Kelautan UNDIP. 9 (4): 202-205.

Sari, W dan Rahmad. (2014). Pemanfaatan Penyu oleh Masyarakat Pesisir di Kota Banda Aceh dan Kabupaten Aceh Besar. Prosiding. Seminar Nasional Biotik 2014. UIN Ar Raniry. Banda Aceh. 17-18 Maret 2014.

Satriadi, A., Esti, R., dan Nurul, A. (2003). Identifikasi Penyu dan Studi Karakteristik Fisik Habitat Penelurannya di Pantai Samas, Kabupaten Bantul, Yogyakarta. Jurnal Ilmu Kelautan UNDIP. 8 (2): $69-75$.

Sunatmo, T. I. (2009). Mikrobiologi Esensial. Ardy Agency, Jakarta.

Syaiful, N. B., Jabang, N., dan Indra, J. Z. (2013). Penetasan Telur Penyu lekang (Lepidochelys olivacea Eschscholtz, 1829) pada Lokasi Berbeda di Kawasan Konservasi Penyu Kota Pariaman. Jurnal Biologi Universitas Andalas. 2(3): 175-180. 